\title{
Rancang Bangun Sistem Tracer Study Alumni Unsrit Berbasis Web
}

\author{
Romario I. Ruru, John Reimon Batmetan, Don R.G Kabo
}

Program Studi Teknik Informatika Universitas Sariputra Indonesia Tomohon, Tomohon, 95416

\begin{abstract}
ABSTRAK
Teknologi Informasi sudah menjadi pilihan utama dalam menciptakan suatu sistem informasi yang dapat memberikan informasi secara akurat dan tepat. Selama ini dari sistem informasi data pengelolaan alumni pengelolahan masih menggunakan cara dokumen cetak, mengakibatkan pengelolaan data belum dapat dilakukan dengan cepat dan masih sering terjadi kesalahan serta sulit untuk diperbaharui. Tujuan penelitian adalah merancang dan membuat sistem tracer study alumni UNSRIT berbasis web sehingga dapat merangkul dan memperoleh informasi, dan untuk terbangunnya hubungan timbal balik antara alumni dan Universitas Sariputra Indonesia Tomohon. Perancangan sistem menggunakan metode prototype terdiri dari tahapan communication, quick plan, modeling quick design, construction of protoype, deployment delivery and feedback. Pemodelan sistem menggunakan sistem OOP(Object Orientasi Programming) yaitu use case, SKPL(Spesifikasi Kebutuhan Perangkat Lunak), ERD(Entity Relationship Diagram), Alur Penelitian Flow Chart. Pembuatan skripsi ini telah dirancang suatu sistem tracer study alumni unsrit berbasis web. Hasil penelitian ini berhasil membangun sistem tracer study yang berbasis web. Sistem tracer study berhasil melakukan tracer study terhadap 100 alumni dan telah terdokumentasi secara sistematika sehingga menjadi lebih efisien.
\end{abstract}

Kata Kunci: Sistem informasi, Tracer Study, Prototype, UNSRIT, Alumni

\section{PENDAHULUAN}

Data alumni merupakan salah satu contoh dari suatu sistem informasi. Sistem informasi dapat dirancang untuk membantu pekerjaan dari suatu instansi pendidikan di perguruan tinggi. Sistem informasi dapat juga mengolah data sampai memberikan data secara lengkap lewat tersedianya layanan informasi berbasis web. Sejauh ini belum ada penerapan sistem informasi pendataan alumni berbasis web di Universitas Sariputra Indonesia Tomohon (UNSRIT). Dalam pengelolaan data alumni UNSRIT masih dengan sistem manual atau dengan dokumen cetak, buku, atau sebagainya. Maka diperlukan suatu sistem informasi yang dapat menginformasikan data secara akurat dari para alumni yang ada. Pengelolahan data alumni yang masih menggunakan cara dokumen cetak, mengakibatkan pengelolaan data belum dapat dilakukan dengan cepat dan masih sering terjadi kesalahan serta sulit untuk diperbaharui. Permasalahan ini dapat ditanggulangi dengan suatu metode yang sedang berkembang yaitu sistem pemograman. Salah satunya dengan pemrograman sistem tracer study. Tracer study atau dikenal juga dengan nama graduate survey, follow-up survey, atau survey lulusan, berguna untuk melacak keberadaan lulusan dari sebuah institusi setelah mereka meninggalkan institusinya. Survei lulusan ini bertujuan untuk memberikan umpan balik atas proses pembelajaran yang pernah didapatkan semasa di perguruan tinggi yang dibutuhkan dalam dunia kerja. Kondisi perkembangan Teknologi diseluruh dunia masa kini makin berkembang sejak terciptanya internet. Internet juga bisa sangat berpengaruh dalam kehidupan manusia, contohnya dalam pekerjaan, persekolahan, perkuliahan, juga dalam bidang bisnis dan lain-lain. Penerapan sistem informasi menjadi sangat berpengaruh dalam kegiatan kerja. Teknologi memiliki lebih dari satu definisi. Salah satunya adalah pengembangan dan aplikasi dari alat, mesin, material, dan proses yang menolong manusia menyelesaikan masalahnya. Teknologi dibuat atas dasar ilmu pengetahuan dengan tujuan untuk mempermudah pekerjaan manusia. Teknologi dapat dilengkapi dengan algoritma komputasi sehingga menjadi lebih efektif dalam bekerja. 
Kemajuan teknologi adalah sesuatu yang tidak bisa kita hindari dalam kehidupan ini, karena kemajuan teknologi akan berjalan sesuai dengan kemajuan ilmu pengetahuan. Setiap inovasi diciptakan untuk memberikan manfaat positif bagi kehidupan manusia. Teknologi memberikan banyak kemudahan, serta sebagai cara baru dalam melakukan aktifitas manusia. Khusus dalam bidang teknologi masyarakat sudah menikmati banyak manfaat yang dibawa oleh inovasi-inovasi yang telah dihasilkan dalam dekade terakhir ini. Namun demikian, keberadaan sebuah perguruan tinggi di tentukan oleh kualitas Iulusan. Kualitas Iulusan dapat dilihat dari kehidupan sosial Iulusan tersebut atau pekerjaan yang sedang dilakukannya setelah lulus dari perguruan tinggi. Berdasarkan kondisi tersebut, perguruan tinggi harus mampu memetakan kompetensi lulusan yang relevan dengan kondisi eksternal dilapangan. Khususnya suatu sistem informasi untuk data alumni dari lulusan perguruan tinggi. Perangkat lunak sistem manajemen informasi ini diharapkan dapat membantu pengelolahan data alumni UNSRIT. Selanjutnya, perangkat lunak sistem manajemen informasi ini diharapkan dapat menghasilkan informasi yang dibutuhkan secara efektif dan efisien ketika dalam pengambilan keputusan oleh Universitas Sariputra Indonesia Tomohon (UNSRIT) dalam mengelolah sumber daya manusia yang berasal dari alumni UNSRIT. Maka dari itu penulis membuat " RANCANG BANGUN SISTEM TRACER STUDY ALUMNI UNSRIT BERBASIS WEB “.

\section{METODE PENELITIAN}

Penelitan ini menggunakan metode penelitian Prototyping. Prototyping adalah pengembangan yang cepat dan pengujian terhadap model kerja (prototype) dari aplikasi baru melalui proses interaksi dan berulangulang yang biasa digunakan ahli sistem informasi dan ahli bisnis. Prototyping disebut juga desain aplikasi cepat (Rapid Application
Design/RAD) karena menyederhanakan dan mempercepat desain sistem. (O'Brien, 2005).. Pada tahun 1960-an Teknik-teknik prototyping pertama cepat menjadi diakses pada tahun delapan puluhan kemudian dan mereka digunakan untuk produksi komponen prototype. Langkah-langkah Prototyping yaitu;

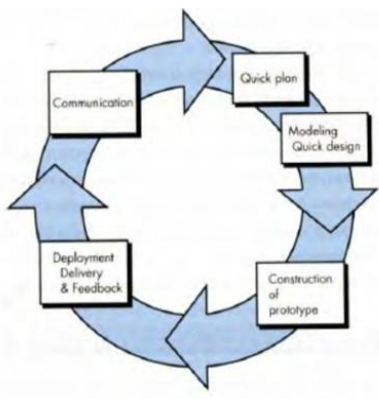

Gambar 1. Metode Prototype

Penjelasan Gambar 1. Metode Prototype:

1. Communication

Peneliti akan berkomunikasi dengan pengguna sistem yaitu, tiap-tiap fakultas UNSRIT, (Dekan, Dosen, dan Staff/admin). Pengambilan data akan didapatkan dengan cara wawancara, observasi, dan dokumentasi.

\section{Quick Plan}

Pada tahap ini penelti akan membuat rencana awal menggunakan data-data yang didapatkan dari user.

\section{Modeling Quick Design}

Pada langkah ini peneliti akan memodelkan sistem yang akan dibangun. Modeling ini berupa pengantara sistem menggunakan Use Case, desain database, $E R D$, dan rancangan interface.

\section{Construction of prototype}

Pada langkah ini peneliti akan melakukan coding menggunakan bahasa pemrograman PHP dengan Database MySQL. Hasilnya berupa aplikasi Web yang dapat berfungsi dengan baik. Web akan digunakan oleh Dekan, Dosen, Staff, dan Alumni UNSRIT.

5. Deployment Delivery and Feedback

Tahapan ini merupakan langkah terakhir dari metode prototyping. Pada tahapan ini peneliti akan melakukan evaluasi dan testing pada sistem yang telah dibangun. Hasil evaluasi dan testing ini akan digunakan kembali untuk memperbaiki sistem yang teah dibangun. Metode prototyping ini akan menggunakan 2 kali putaran tahapan prototyping, sehingga aplikasi yang di hasilkan dapat menjadi baik sesuai dengan harapan user. 
Waktu dan Tempat Penelitian dilakukan Selama bulan Februari 2017 sampai bulan April 2017 di Universitas Sariputra Indonesia Tomohon (UNSRIT).

Teknik Pengumpulan data menggunakan metode Wawancara, Observasi, Dokumentasi, yaitu :

\section{Wawancara}

Wawancara merupakan teknik penelusuran dari fakta dimana analisis sistem mengumpulkan informasi dari individu-individu melalui interaksi face to face (Whitten, 2004).

\section{Observasi}

Observasi merupakan teknik penelusuran fakta dimana analisis sistem berpatisipasi atau melihat seseorang melakukan aktivitas untuk mempelajari sistem (Whiiten, 2004)

3. Dokumentasi

Teknik pengumpulan data ini digunakan untuk mendapatkan data-data serta teori-teori yang mendukung dalam pembuatan sistem Tracer Study data alumni UNSRIT. Metode ini dilakukan dengan mencari literature yang dapat mendukung penelitian. Metode pengumpulan data yang dilakukan oleh penulis berdasarkan buku-buku literature yang dapat digunakan sebagai penunjang dalam pemecahan masalah yang dihadapi penulis. Standar pengambilan data dan pengelolahan data alumni mahasiswa UNSRIT.

Metode Penelitian ini ada juga Kerangka Berpikir-nya untuk penelitian ini yaitu;
1. Isu Strategis

Isu Strategis disini menjelaskan bahwa dalam pengumpulan data alumni UNSRIT masih dalam bentuk pendataan manual, dan belum adanya pendataan dengan sistem tracer study berbasis web.

\section{Identifikasi Masalah}

Pada tahap ini dirangkai dengan identifikasi masalah dengan beberapa pertanyaan, yaitu bagaimana agar lebih mudah dalam pendataan alumni dan bagaimana perancangan tracer study berbasis web.

\section{Pengembang Perangkat Lunak}

Untuk dapat dimengerti oleh mesin, dalam hal ini adalah computer, maka program Tracer Study Alumni UNSRIT berbasis web akan dibentuk kedalam bahasa pemrograman melalui proses coding dengan PHP dan MYSQL. Tahap ini merupakan pengembangan sistem Analysis, Design, Coding, Testing dan Implementasi menggunakan metode Prototype.

\section{Hasil Penelitian}

Penelitian ini diharapkan mampu membangun sebuah sistem tracer study alumni secara mudah dan cepat. Harapannya pendataan alumni UNSRIT jadi lebih mudah dengan sistem tracer study berbasis web.

Pemodelan untuk sistem dalam penelitian ini menggunakan Sistem OOP (Object Orientasi Programming) yaitu;

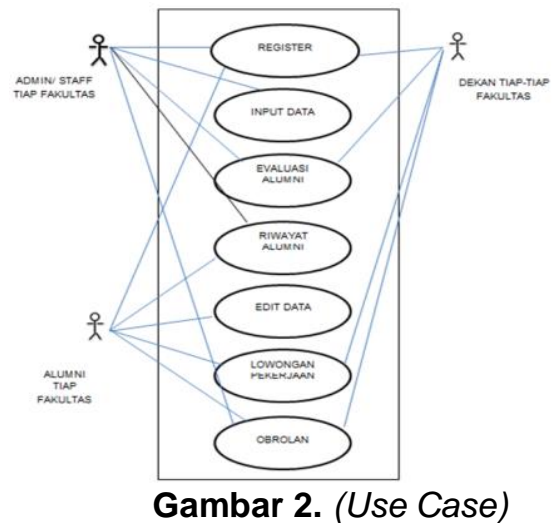

Use Case merupakan sebuah teknik yang digunakan dalam pengembangan sebuah software atau sistem informasi untuk menangkap kebutuhan fungsional dari sistem yang bersangkutan, Use Case menjelaskan interaksi yang terjadi antara 'aktor' - inisiator dari interaksi sistem itu sendiri dengan sistem yang ada, sebuah Use Case direpresentasikan dengan urutan langkah yang sederhana.
Perilaku sistem adalah bagaimana sistem beraksi dan bereaksi. Perilaku ini merupakan aktifitas sistem yang bisa dilihat dari luar dan bisa diuji. Perilaku sistem ini dicapture di dalam use case. Use case sendiri mendeskripsikan sistem, lingkungan sistem, serta hubungan antara sistem dengan lingkungannya. 


\section{HASIL DAN PEMBAHASAN}

Tracer Study adalah: (1) Mengidentifikasi profil kompetensi dan keterampilan Iulusan; (2) Mengetahui relevansi dari pelaksanaan kurikulum yang telah diterapkan di perguruan tinggi dengan kebutuhan pasar tenaga kerja dan pengembangan profesional di dalam kompetensi jurusan; (3) Untuk mengevaluasi hubungan dari kurikulum dan studi di jurusan sebagai pengembangan keilmuan; (4) Sebagai kontribusi dalam proses akreditasi jurusan. Penelusuran Iulusan (Tracer Study) adalah salah satu hal strategis yang harus dilakukan oleh setiap institusi pendidikan. (Schomburg, 2003).

Web Tracer Study ini dapat dijalankan dari berbagai computer yang memakai resolusi yang berbeda, namun yang terbaik memakai resolusi 960x1024. Web ini dibangun dengan menggunakan bahasa HTML, CSS, PHP, JAVASCRIPT dan FLASH. Web ini dapat diaksesoleh client pada lingkungan sistem operasi apapun yang mempunyai aplikasi penjelajah situs (web browser). Pengaksesan Website ini untuk admin di tiap-tiap Fakultas Universitas Sariputra Indonesia Tomohon (UNSRIT).

Karakteristik dari pengguna perangkat lunak Website Tracer Study adalah (1)Administrator Fakultas: Memahami pengoperasian aplikasi berbasis desktop. CRUD data Alumni UNSRIT. (2)Alumni: Input Data, Posting Lowongan Pekerjaan, Update Data. (3)Dekan Fakultas: Memantau website tracer study, Update kegiatan Ikatan Alumni dan lowongan pekerjaan.

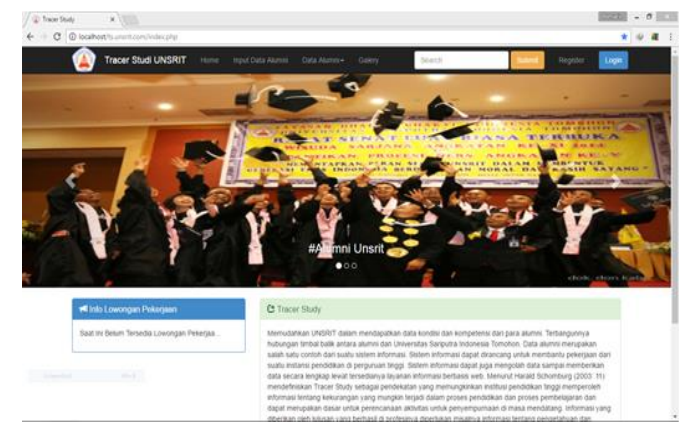

Gambar 3. Desain Halaman Website Tracer Study

Pada tampilan ini berisi tampilan awal dari user desain interface, yaitu, dari kiri atas ada logo UNSRIT, nama website, Home, Input Data Alumni, Data Alumni yang di dalamnya ada perFakultas yang ada di UNSRIT, Gallery, Search,
Register dan login yang menjadi awal tampilan dari website tracer study alumni UNSRIT juga ada tampilan untuk lowongan pekerjaan, sekilas tentang tracer study.

\section{KESIMPULAN}

\section{Kesimpulan}

Hasil penelitian ini dapat menyimpulkan bahwa sistem tracer study alumni UNSRIT berbasis web telah dapat dirancang dan dibangun menggunakan metode prototype. Hasil rancangan telah dapat dibangun sebuah sistem tracer study berbasis web, menggunakan bahasa pemrograman PHP \& MYSql untuk membangun database. Hasil dari tracer study ini telah dapat memetakan kondisi dan kompetensi Alumni UNSRIT. Penelitian ini telah dapat menyimpulkan bahwa sistem tracer study dapat dibangun secara mudah dengan teknik perancangan metode prototyping sehingga dapat implementasikan di Universitas Sariputra Indonesia Tomohon (UNSRIT).

Saran

Penelitian ini dapat memberi saran yang dapat dilakukan antara lain:

1. Sistem Tracer Study disarankan untuk mengelolah sistem ini adalah: admin ditiap-tiap Fakultas Universitas Sariputra Indonesia Tomohon (UNSRIT)
2. Sistem Tracer Study disarankan diimplementasikan kepada Alumni Universitas Sariputra Indonesia Tomohon (UNSRIT) sehingga terbangunnya hubungan timbal balik antara alumni dan Kampus Universitas Sariputra Indonesia Tomohon (UNSRIT). 


\section{DAFTAR PUSTAKA}

O' Brien, James A. (2005). Pengantar Sistem Informasi: Perspektif Bisnis dan Manajerial.(12 $2^{\text {th }} \quad$ Editon). Salemba edition. Salemba Empat, Jakarta.

Schomburg, Harald (2003). Handbook for Graduate Tracer Study. Moenchebergstrasse Kassel, Germany: Wissenschaftliches Zentrum für Berufs- und Hochschulforschung, Universität Kassel.

Whitten, Bentley, Dittman. 2004. Metode Desain \& Analisis Sistem. Yogyakarta: Penerbit Andi

Metode Prototype (Sumber: http://lindroidspica.blogspot.co.id/2011/09/m etode-dan-model-proses-rekayasa.html)

J. R. Batmetan Suyoto, J. D. C. L. Suares, "An Empirical Investigation on Customer Behavior to Adopt Mobile Commerce among the $Y$ Generation in Indonesia", Sriwijaya International Conference On Engineering, Science \& Technology [SICEST 2016], 2016

J.R. Batmetan, "Algoritma Ant Colony Optimization (ACO) untuk Pemilihan Jalur Tercepat Evakuasi Bencana Gunung Lokon Sulawesi Utara", Jurnal Teknologi InformasiAITI, 2016, vol.13, no.2, pp 31-48

L. Madeso, D. R. Kabo, J. R. Batmetan, " Rancang Bangun Sistem Pakar Penentuan Status Gizi Pada Balita Menggunakan Metode Forward Chainning", E-Jurnal UNSRIT, vol.2

J. R. Batmetan, V. R. Palilingan, " Higher Education Students' Behaviour to Adopt Mobile Learning", IOP Conference Series: Materials Science and Engineering, 2018, vol. 306, Issue 1, pp. 012110 (2018)

V. R. Palilingan, J. R. Batmetan, "Incident Management in Academic Information System using ITIL Framework", IOP Conference Series: Materials Science and Engineering, 2018, vol. 306, Issue 1, pp. 012110 (2018)

J. R. Batmetan, A. J. Santoso, Pranowo, " A Multiple-Objective Ant Colony Algorithm for Optimizing Disaster Relief Logistics", Advanced Science Letters, 2017, vol.23, no.3, pp. 2344-2347

M. L. Tompodung, F. Supit, J. R. Batmetan, " Rancang Bangun Aplikasi Sensus Penduduk Berbasis Android", Buletin Sariputra, 2017, vol.7, pp. 57-61

J. R. Batmetan, " Optimasi Strategi Smart Environment Dalam Mitigasi Bencana Menggunakan Multi-Objective Aco (Mo-Aco) Algorithm", Pasca Sarjana Magister Teknik
Informatika Universitas Atma Jaya Yogyakarta, 2016 